\title{
God in de (Post)moderne cultuur - George Steiner over transcendentie in kunst en cultuur
}

\author{
W Stoker ${ }^{1}$
}

(Vrije Universiteit Amsterdam)

\section{ABSTRACT \\ God in the (Post modern culture - George Steiner on transcendence in art and culture}

In his 1989 study Real Presences the well-known philosopher and literary scholar George Steiner argues that there is a crisis in philosophy, art and literature. The contract between word and world has been broken, whereby we can no longer make any assertions about human beings and the world. Communication thus becomes problematic. The (post)modern world has become nihilistic. Steiner provides a theological explanation for what in his view is a serious crisis in (post)modern art and in Western culture in general: he blames this crisis for the loss of transcendence through the "death of God".

This paper will show that Steiner, on the basis of his metaphysical view of transcendence ends up with the dilemma of having to choose between transcendence or immanence/nihilism. This dilemma is unnecessary to the extent that it suggests that transcendence is identical with metaphysical transcendence. If we reject this identification, then the alternative for Steiner's metaphysical transcendence is not only immanence, viewed as nihilism but can also be another form of transcendence. And this casts another light on the crisis Steiner has indicated in culture.

De bekende filosoof en literatuurwetenschapper George Steiner stelt in zijn studie Real Presences uit 1989 dat er een crisis is in filosofie, kunst en literatuur. Het contract tussen woord en werkelijkheid is verbroken waardoor we geen uitspraken meer kunnen doen over mens en wereld en daarmee wordt communicatie een probleem. De (post)moderne wereld is nihilistisch geworden. Taal verwijst naar zichzelf, de ene tekst verwijst eindeloos naar andere teksten. Steiner

1 Navorsingsgenoot, Prof C J A Wethmar, Departement Dogmatiek en Christelike Etiek, Universiteit van Pretoria. 
geeft een theologische verklaring voor de zijns inziens ernstige crisis in de (post)moderne kunst en in de westerse cultuur in het algemeen. Hij wijt haar aan verlies van transcendentie door de 'dood van God' en meent dat kunst en cultuur alleen van hun nihilisme genezen kunnen worden door de erkenning van Gods tegenwoordigheid zoals de titel Real Presences aangeeft.

Sowel in Nederland als in Zuid Afrika staat de christelijke kerk onder druk. Conrad Wethmar is als kenner van de ecclesiologie ondermeer bezig met de vraag van de plaats van de kerk in een plurale cultuur. Als leerling van Berkouwer en Meuleman is hij doordrongen van de wisselwerking tussen kerk en cultuur. In dat verband bespreek ik de plaats van transcendentie in de westerse cultuur aan de hand van Steiners visie daarop zoals uitgewerkt in zijn Real Presences. ${ }^{2}$

\section{STEINERS VISIE OP DE CULTUUR}

\subsection{Verlies van transcendentie}

Het contract tussen woord en wereld is aldus Steiner verbroken in de periode van 1870-1930. "It is this break of the covenant between word and world which constitutes one of the very few genuine revolutions of spirit in Western history and which defines modernity itself" (Steiner 1991a: 93). Het woord als Logos dat het zijn zegt, leeft niet meer. We leven thans in een tijd van na het woord, de epiloog. De vraag is hoe we communiceren kunnen, nu het woord zonder betekenis is geworden. Voor deze crisis verwijst Steiner niet alleen naar Nietzsche. De dood van God is ook aan te wijzen bij de dichter Mallarmé (1842-1898) voor wie de taal geen externe referentie kent. Het woord roos heeft geen steel, blad of doorn; evenmin kleur of geur. Het is op zich enkel een willekeurig fonetisch, leeg teken. Het woord roos verwijst niet meer naar de bloem die we kunnen zien, ruiken en aanraken (Steiner 1991a: 94v.). Het woord heeft zijn functie van representatie verloren. De dichter Rimbaud (1854-1891) deconstrueerde het subject waardoor de auteur van een tekst dood is verklaard.

Where the 'I' is not 'I' but a Magellanic cloud of momentary energies always in process of fission, there can be no authorship in any single, stable sense. The

$2 \quad$ Ik citeer uit de paperback uitgave van 1991. 
maker's - the poet's, the painter's, the composer's - will and intentionality in regard to his work can have no fixed locus. It becomes a logical and a psychological fiction

(Steiner 1991a:100).

Rimbauds deconstructie van het zelf staat aan de bakermat van de latere deconstructie van de taal, van het destabiliseren van betekenissen zoals we dat bij Barthes en Derrida zien (Steiner 1991a:101). Hiermee worden volgens Steiner de fundamenten van het hebreeuws-hellenistische-cartesiaanse gebouw waarin de ratio en de 'psychologie' van onze communicatie is gehuisvest, op losse schroeven gezet (Steiner1991a:101). Daarmee komt een einde aan een 'Logos-aesthetica en hermeneutiek' met hun verwijzing naar auteurschap en naar mogelijke autoriteit die inherent is aan woord of begrip (Steiner1991a:101). Steiner ziet de crisis in heel de westerse cultuur aanwezig. Hij verwijst naar het Wenen van Karl Kraus, Wittgenstein en Freud rond de $19^{\mathrm{e}}$ eeuw-wisseling. Daarover kan men een impressieve beschrijving lezen in Janiks en Toulmins Het Wenen van Wittgenstein. Thans dolen we rond in de wereld van de tekst die niet meer buiten zichzelf verwijst zoals Steiner het bekende woord van Derrida - "Il n' y a pas de hors-texte" - lijkt te interpreteren. De literaire leesmethode van de deconstructie acht Steiner nihilistisch: "de scherpzinnige trivialisaties, het speelse nihilisme van de deconstructie bezitten inderdaad de verdienste van eerlijkheid. Ze leren ons 'dat uit niets niets voortkomt' " (Steiner 1991b:163). De crisis in de cultuur samenvattend zegt hij:

The abrogation of the contract between word and world, the decomposition of the self as we observed them in Mallarmé and Rimbaud (Baudelaire is also a source) found a logical employment in Nietzsche's subversion of 'truth' and of 'truthtelling' and in Freud's critique of intentionality. Deconstruction draws the consequence. Without having either to affirm or to deny the 'death of God' ... deconstruction teaches us that where is no 'face of God' for the semantic marker to turn to, there can be no transcendent or decidable intelligibility. The break with the postulate of the sacred is the break with any stable, potentially ascertainable meaning of meaning

(Steiner 1991a:132; - 1991b:146, 55). 


\subsection{Steiners oplossing}

Steiner ziet de oplossing voor de crisis in kunst en communicatie liggen in de theologie. Hij meent dat het aannemen van Gods presentie nodig is voor een coherente opvatting van taal en voor een coherente verklaring van het menselijke vermogen om met taal betekenis en gevoel te communiceren (Steiner 1991a:3). Gods presentie acht hij niet alleen nodig waar het om taal gaat, maar ook voor de esthetische betekenis in het algemeen, in literatuur, (beeldende) kunsten en muziek. Hij meent dat het waagstuk van de 'betekenis van de betekenis' een 'wager on transcendence' is.

This wager - it is that of Descartes of Kant and of every poet, artist, composer of whom we have explicit record predicates the presence of a realness, of a 'substantation' (the theological reach of this word is obvious) within language and form. It supposes a passage, beyond the fictive or the purely pragmatic, from meaning to meaningfulness

(Steiner 1991a: 4,50,134,216; - 1991b:161).

Kortom: woorden kunnen naar werkelijkheid verwijzen als we transcendentie of een werkelijke presentie aannemen zoals in een Logos-aesthetica gebeurt.

\subsection{Kunst als een religieuze ervaring}

Voor een goed begrip van Steiners visie op de relatie van God en kunst wijs ik op zijn kunstbeschouwing. Hij benadrukt dat kunst het betreft hier hoge kunst: de klassieke en moderne tragedies, Dante, Milton, Dostojewski, Joyce enz. - iets anders is dan wetenschap. Aan de wetenschappelijke bestudering van kunst kunnen we niet de eis van verificatie of falsificatie stellen (Steiner 1991a:68,75). Dat de ene interpretatie beter is dan de andere van een kunstwerk is volgens hem niet hard te maken (Steiner 1991a:76; 1991b:150).

Kunst moeten we niet laten verdampen in de secundaire literatuur over kunst, maar we moeten een kunstwerk zelf ter hand nemen (Steiner 1991a:49). Anders dan de leesmethode van deconstructie beschouwt Steiner namelijk een kunstwerk of een tekst niet als iets temidden van teksten, maar als een werk voorafgaande aan alle inter-textualiteiten. Het is hun bron van zijn (Steiner 1991a:150). 
Kunst lijkt op religie. Zoals religie ons leven verandert, zo doet kunst dat ook volgens het bekende woord uit een gedicht van Rilke Archaïsche Apollotorso: "Du musst dein Leben ändern” (Rilke 2000:9; Steiner 1991a:142). In tweeërlei zin lijkt kunst op religie: in de manier waarop de lezer of de kijker omgaat met kunst én de manier waarop kunst tot stand komt. Ik begin met dit laatste.

Steiner benadrukt het scheppende karakter van het maken van een kunstwerk. Met een variatie op Leibniz' vraag 'waarom is er iets en niet niets?', vraagt hij waarom er kunst is, waarom er poëtische schepping is. De wereld zelf lijkt al voldoende rijk en onuitputtelijk met zijn vormen en kleuren. Kijk naar het wonder van design van het menselijk lichaam, waarom dan nog kunst als rijk van fictie? Steiners antwoord is dat er esthetische schepping is, omdat er schepping is (Steiner 1991a:201). De basis van ons bestaan is de onpeilbare verwondering dat we er zijn. Kunst is op een bepaalde manier imitatio van Gods scheppingsdaad. "Outside Creation Myths there is no Ur-werk, no primordial, autochtonous, self-born act of aesthetic invention or formulation" (Steiner 1991a:150). De kunstenaar heeft wel de droom om geheel iets nieuws te maken, maar kunst is altijd een schepping afhankelijk van het geschapen materiaal en is daarom altijd een schepping na de oorspronkelijke schepping (Steiner 1991a:202). Het gaat niet om mimesis als nabootsen zoals Plato kunst beschouwde. De verhouding met Gods scheppingsdaad ziet Steiner als volgt: "I believe that the making into being by the poet, artist and, ... by the composer is counter-creation" (Steiner 1991a:203). Kunst is in mimetisch opzicht niet neutraal, maar strijdlustig en beoogt effect. Zoals Gods scheppingsdaad een daad van vrijheid is, zo geldt dat ook van het maken van een kunstwerk. Het kan zijn of niet zijn.

Niet alleen het kunstwerk komt voort uit vrijheid maar dat geldt ook voor de ontmoeting van de beschouwer ermee. Het kunstwerk kan zich al dan niet geven en de beschouwer kan zich er al dan niet voor openstellen. Dat is een ontmoeting van twee 'vrijheden'. Kunst benaderen we vanuit een houding van verwondering over het gift-karakter ervan, omdat het er ook niet had kunnen zijn (Steiner 1991a: 152; 174). Steiner ziet een analogie met de ontmoeting met de 'transcendente' ander, een geliefde of een gast. "Wanneer men 'bewoond' wordt door muziek, beeldende kunst, literatuur, wanneer men verantwoordelijk, aansprakelijk wordt gemaakt voor dat onderdak zoals een gastheer voor een gast ...komt 
dat neer op de ervaring van het alledaagse mysterie van een reële presentie" (Steiner 1991b:160). De houding tegenover kunst is die van de hoofse liefde en tact (Steiner 1994:276). De ontmoeting met kunst ziet hij zelfs als een godsontmoeting (Steiner 1991a:154). Zo beschrijft hij als volgt de ontmoeting met kunst in termen van de aankondiging door de engel uit het evangelie:

The encounter with the aesthetic is, together with certain modes of

religious and of metaphysical experience, the most 'ingressive', transformative summons available to human experiencing. Again, the shorthand image is that of an Annunciation, of a 'terrible beauty' or gravity breaking into the small house of our cautionary being. If we have heard rightly the wing-beat and provocation of that visit, the house is no longer habitable in quite the same way as it was before. A mastering intrusion has shifted the light (that is very precisely, non-mystically, the shift made visible in Fra Angelico’s Annunciation)

(Steiner 1991a:143).

De ontmoeting met kunst krijgt zo het karakter van een religieuze ervaring. Dat is Steiners 'wager on transcendence'. God is tegenwoordig in het grote kunstwerk en in de ontmoeting ermee: "there is in the art-act and its reception ... in the experience of meaningful form, a presumption of presence" (Steiner 1991a:214). Zo meent hij dat alle grote kunst religieus is geïnspireerd (Steiner 1991a:216). De 'betekenisvolle vorm' kan niet uit immanentie, maar alleen vanuit transcendentie worden verklaard (Steiner 1991a:224,229). "Wanneer wij waarachtig lezen, wanneer de ervaring zin moet hebben, doen wij dat alsof de tekst (het stuk muziek, het kunstwerk), de incarnatie (de gedachte heeft een sacramentele achtergrond) is van een reële presentie van betekenis. Deze reële presentie, zoals bij een icoon, zoals bij de uitgevoerde metafoor van heilig brood en wijn, is in laatste instantie niet te herleiden tot enige andere formele articulatie, tot enige analytische deconstructie of parafrase" (Steiner 1991b:159). Deze reële presentie van betekenis is volgens Steiner thans verloren gegaan. Vandaar dat hij tengevolge van de 'dood van God' een crisis in de cultuur signaleert. Aan het slot van zijn boek vergelijkt hij onze tijd met Stille Zaterdag van de Goede Week: 
But ours is the long day's journey of the Saturday. Between suffering, aloneness, unutterable waste on the one hand and the dream of liberation, of rebirth on the other. In the face of the torture of a child, of the death of love which is Friday, even the greatest art and poetry are almost helpless. In the Utopia of the Sunday, the aesthetic will, presumably, no longer have logic or necessity. The apprehensions and figurations in the play of metaphysical imagining, in the poem and the music, which tell of pain and of hope, of the flesh which is said to taste of ash and of the spirit which is said to have the savour of fire, are always Sabbatarian. They have risen out of an immensity of waiting which is that of man. Without them, how could we be patient?

(Steiner 1991a:232; - 1991b: 163).

Men kan verschillende vragen stellen bij de wijze waarop Steiner God en de moderne cultuur met elkaar verbindt. Kan men God zo maar invoeren in de literatuurwetenschap? Hoe dient men volgens Steiner als niet-gelovige literatuur te lezen? Is dat wel mogelijk? Men heeft Steiners visie wel bekritiseerd als re-theologisering van de kunst of estheticering van God (Kuschel 1993:147). Als theoloog kan men vragen stellen bij de massieve wijze waarop Steiner over Gods presentie spreekt (Dalferth 1996:48). Hoe belangrijk deze vragen ook zijn, ik beperk mij tot een onderzoek naar Steiners spreken over transcendentie.

Ik stel twee zaken aan de orde: is er wel sprake van verlies van transcendentie in de westerse cultuur of verschijnt transcendentie thans in andere gestaltes (par. 2)? De tweede kwestie betreft de nauwe band tussen kunst en religieuze transcendentie bij Steiner. Hoe moeten we ons die precies voorstellen? Bij dit laatste beperk ik mij tot mijn eigen traditie, en zeg iets over kunst en christelijk geloof (par.3).

\section{TRANSCENDENTIE}

\subsection{Metafysische transcendentie}

Voor de beantwoording van de eerste vraag ga ik in op de manier waarop Steiner zelf transcendentie gebruikt. Hij blijkt een metafysische opvatting van transcendentie te hanteren zoals dat gebeurt in het funderingsdenken. Hij beschouwt zoals gezegd 
transcendentie als garant van betekenis en communicatie. Dit doet herinneren aan Descartes' argumentatie voor de betrouwbaarheid van onze waarneming in de zesde Meditatie. Na vastgesteld te hebben dat ik als denkend mens besta en bepaalde onbetwijfelbare opvattingen heb zoals de godsopvatting, stelt Descartes de vraag aan de orde hoe wij weten dat er iets aan onze voorstellingen van de dingen beantwoordt. De garantie daarvoor is God die ons niet kan bedriegen. Zo voert ook Steiner God of transcendentie op als garantie voor het verbond van woord en wereld. Hij zelf bevestigt deze verwijzing naar Descartes (Steiner 1991b:158v).

Steiner spreekt weliswaar van een 'wager on transcendence'. Dat lijkt meer op Pascals spreken over God dan op de wijze zoals Descartes dat doet in de Méditations. Steiner noemt hen zelfs in dit verband in één adem (Steiner 1991b:215). Voor zijn argumentatie beroept hij zich echter op Descartes, dus niet op de God van Abraham, maar op de God van de filosofen die met Godsbewijzen kan worden vastgesteld. God heeft hier de functie van garantie. Daarmee blijft Steiner in het zelfde wetenschapsklimaat van de logisch-positivist die hij juist bestrijdt door voor de literatuurwetenschap verificatie met behulp van sense-data af te wijzen. De logisch positivist en Steiner zijn klassieke funderingsdenkers en gaan uit van onbetwijfelbare uitgangspunten. Steiner zoekt het fundament van 'betekenis' in transcendentie, in God als Logos, terwijl voor de logisch-positivist het fundament voor betekenisvolle kennis ligt in neutrale, onbetwijfelbare sense data, zintuiglijk waarneembare gegevens. Dit klassieke funderingsdenken was in de tijd dat Real Presences (1989) werd gepubliceerd, al een gepasseerd station. In de nieuwere wetenschapsfilosofie van Quine en Kuhn erkent men dat wij altijd en noodzakelijk vanuit een bepaald perspectief, een bepaalde vooringenomenheid de werkelijkheid benaderen en dat we dat perspectief wel kunnen corrigeren maar nooit kunnen opheffen.

Waar het mij om gaat is dat Steiner vanuit zijn metafysische transcendentieopvatting komt tot het dilemma transcendentie of immanentie/nihilisme. Dit dilemma is inzoverre onjuist als het suggereert dat transcendentie identiek is met metafysische transcendentie. Wijst men dit af, dan hoeft het alternatief voor Steiners metafysische transcendentie niet alleen immanentie, opgevat als nihilisme, te zijn, maar het alternatief kan dan ook een 
andere vorm van transcendentie zijn. Er valt dan een ander licht op de door Steiner gesignaleerde crisis in de cultuur.

\subsection{Verlies van transcendentie?}

Op de vraag of transcendentie uit onze cultuur is verdwenen verwacht men in eerste instantie een empirisch-sociologisch antwoord. Onderzoeken in Nederland geven aan dat er in toenemende mate aandacht voor spiritualiteit is en dat daarom deze vraag empirisch ontkennend is te beantwoorden. Steiner wil met zijn bewering van verlies van transcendentie iets anders aan de orde stellen, namelijk een systematisch-filosofische cultuurkwestie. De afwijzing van (metafysische) transcendentie impliceert de verbreking van het contract van woord en werkelijkheid en daarmee nihilisme. Steiner is kennelijk zo overtuigd van het goed recht van zijn metafysische opvatting van transcendentie dat hij niet onderkent dat de cultuurcrisis er juist door is opgeroepen. Hij poneert zijn opvatting van Logos-aesthetica en van metafysische transcendentie alsof er niets is gebeurd in de wetenschapsfilosofie en kentheorie, alsof het klassieke funderingsdenken nog een erkende positie is.

Het verval van metafysische transcendentie heeft verschillende reacties opgeroepen. Steiner wijst terecht voor de crisis in de taal op de Franse dichters Mallarmé en Rimbaud, hoewel hier ook sprake is van een nieuw perpectief op het andere zoals we nog zullen zien. De reactie op de metafysische transcendentie is soms die van radicale immanentie. In de theologie verwijs ik daarvoor naar Altizer die theologisch verdedigt dat God het andere wil zijn en zich heeft ontledigd en daarmee radicaal immanent is geworden in onze werkelijkheid. Altizer wijst daarmee elke transcendentie af en pleit voor radicale immanentie waarin elke transcendentie is verdwenen. Dit moet in termen van Hegels dialectiek worden verstaan, het resultaat van de negatie van de negatie is een algehele affirmatie die alle sporen van onverzoend anderszijn overwint met als resultaat een radicaal immanent opgevatte God (Taylor 1992:155, Prosman 2007:293-305). De traditionele christelijke God is bij Altizer veranderd in een anomieme presentie in de cultuur (Altizer 1980:1936). In de pop-art uit de jaren '60 ziet men iets soortgelijks zonder de religieuze kleuring van immanentie zoals bij Altizer. De ware werkelijkheid is nu immanent en is het beeld zelf geworden. Er is alleen maar oppervlakte. Het beeld is tot simulacrum geworden zonder oorsprong en zonder verwijzing naar een geestelijke 
werkelijkheid. Er is niets uit te drukken. Zo schilderde Warhol zijn One-Dollar-Bills (1962) en Campbell's Soup Cans (1965) en Jaspers Johns zijn Gray Numbers (1958).

Transcendentie valt niet samen met de metafysische opvatting ervan, maar kan ook anders worden beschreven. Steiner geeft zich van deze mogelijkheid geen rekenschap. In een artikel over Heidegger, oorspronkelijk verschenen in 1989, het zelfde jaar van de herziene uitgave van zijn boek Martin Heidegger, merkt Steiner op dat Heidegger 'transcendentie in de theologische en de neoplatonistische betekenis' bekritiseert (Steiner 1991c:173). Tevens constateert hij dat het werk van Heidegger niet vanuit de immanentie is geschreven en wijst hij op diens analyse van Hölderlin en van Van Gogh, waarin erkenning is van het “'anders-zijn' van de absolute presentie, van ontologische zelfbetekenis, waaraan hij [Heidegger] van zichzelf geen theologisch-metafysisch betekenis mag geven" (Steiner 1991c:177). Steiner meent terecht dat hier niet anders dan in termen van transcendentie kan worden gesproken, maar, zo voeg ik eraan toe, dan wel op een andere wijze dan Steiner doet. Heidegger, Levinas en Derrida hebben juist in hun kritiek op de door Steiner verdedigde opvatting van transcendentie geprobeerd opnieuw onder woorden te brengen wat transcendentie zou kunnen zijn. De crisis in de cultuur dient men te taxeren als een mogelijke doorgang naar een nieuwe opvatting van transcendentie. Ik laat dat zien aan Steiners voorbeeld van de deconstructie die volgens hem een vorm van nihilisme is. Het doel van deconstructie bij Derrida is niet alleen destructie maar juist ook het open houden van teksten voor het andere en daarmee is er ruimte voor een andere opvatting over transcendentie gegeven dan die van Steiner.

\subsection{Deconstructie}

Derrida's filosofie wordt vaak samengevat in drie stellingen 1. alles is tekst; 2. teksten hebben geen vaste betekenis en verwijzen naar andere teksten; 3. de mens doolt rond in de zich uitzaaiende verzameling van teksten (De Boer 1999:175). Zo'n samenvatting roept het beeld op van een negatieve filosofie die uitmondt in nihilisme. Ten onrechte. Derrida verzet zich juist tegen de opvatting van Steiner volgens welke betekenis een 'transcendentaal betekende' is, het teken als iets dat ten opzichte van elke context een transcendente of transcendentale positie inneemt, een begrip dat voor zijn betekenis niet afhankelijk is van een veld van differenties en 
verwijzingsrelaties, maar boven dit veld staat. De betekenis heeft zo de status van evidente presentie, van een wezen of een innerlijk licht. Deze opvatting is voor Derrida verbonden met een subject dat tegenwoordig is aan zichzelf, over evidentie beschikt en daarmee over de fundamenten van zijn kennis zoals in het funderingsdenken het geval is. Derrida meent dat de bestendige aanwezigheid van de vaste orde van dingen een illusie is. De dingen bestaan in een netwerk van relaties, van contexten verweven met andere netwerken. De werkelijkheid is daarmee geen Dionysische chaos, maar wel is alles in beweging zonder dat er een archimedisch punt is dat alle veranderingen sturing geeft.

Voor deze visie maakt Derrida onder anderen gebruik van een inzicht van Heidegger. Zijn is voor Heidegger geen bestendige aanwezigheid, maar een gebeuren, gebonden aan het tijdsverloop, een heen-en-weer-beweging van onthulling en verhulling. De drie tijdseenheden verleden, heden en toekomst dient men namelijk niet lineair op te vatten, maar gelijk-oorspronkelijk. Toekomst en verleden zijn op een verborgen wijze in het heden werkzaam en dat steeds weer anders omdat het heden verschuift en daarmee toekomst en verleden. Dat is van invloed op betekenissen van gebeurtenissen en de betekenissen van zinnen die we uitspreken. De zinnen die we 'nu' uitspreken staan in een verborgen verband met zinnen die eerder zijn gesproken en ook met zinnen die zullen worden uitgesproken in de toekomst. Wij zien daarom iets in een onthullend en tegelijk verhullend perspectief. Verleden en toekomst veranderen als het heden verandert. Het woord is zo geen beheersbaar instrument meer waarmee we een voorhanden zaak benoemen, maar brengt iets ter sprake wat eerst onbesproken was. Het woord heeft een scheppend karakter en maakt mogelijk dat iets verschijnt als iets. Zo geschiedt waarheid. Met andere woorden: taal is als een fenomeen in de tijd onthullend en verhullend, vol van meerduidigheid en geheim (Van der Syde 1997:15-17).

In plaats van de opvatting van het teken als transcendentaal betekende, beschouwt Derrida met Heidegger en De Saussure het teken als een spoor dat nooit op zichzelf staat. Het verwijst naar iets en gaat naar iets toe. Een taalteken staat in een zich oneindig uitbreidend netwerk van interne verwijzingen. Derrida gebruikt hiervoor behalve de term spoor ook de term 'différance'. Différance betekent dat in iedere ervaring en betekenisarticulatie ondoorgrondelijke differenties werkzaam zijn, hetgeen gepaard gaat 
met het uitstel van definitieve betekenis (Van der Syde 1997:87). Taal vat Derrida breed op: het zijn niet alleen maar woorden, maar ook de werkelijkheid vat hij textueel op. De veel geciteerde en misverstand wekkende uitspraak "Il n' y a pas de hors-texte", hetgeen te vertalen is als "er is geen buiten-tekst", houdt niet in dat er geen werkelijkheid buiten de tekst zou zijn. Die is er wel, maar die dient talig te worden opgevat. Taal heeft dus wel een referentie maar dan wel talig (Derrida 1984:123; De Boer 1999:183). Het lijkt alsof we opgesloten zitten in de taal en doelloos ronddwalen in de zich uitzaaiende verzameling van teksten. Dat is niet het geval. Dat dwalen is namelijk geen einddoel. Naast inscriptie gaat de latere Derrida steeds meer aandacht vragen voor de wending naar het andere van de tekst die hij zoekt aan gene zijde van de tekst en van de ervaring. De deconstructie wilde juist de afsluitende structuren destabiliseren om toegang te krijgen tot het andere.

\subsection{Transcendentie in een andere gestalte}

Is het andere op te vatten als transcendentie in de zin van religieuze transcendentie waarop Steiner doelt met Gods tegenwoordigheid? 'Het andere/de ander' kan, maar hoeft niet naar religieuze transcendentie te verwijzen. Dat hangt van de omschrijving van transcendentie af en van de wijze waarop de term 'het andere' wordt gebruikt. Letterlijk betekent transcendentie iets dat iets anders overstijgt. Zo heeft de mens het vermogen van transcendentie of beter hij is transcendent: als mens heeft hij zich te ontwerpen. Er zijn ervaringen die radicaal van 'beyond' zijn, waar de mens geen greep op heeft.

Het andere kan het onbewuste betekenen zoals bij Freud. Ons handelen wordt mede bepaald door het andere als het onbewuste waar we geen greep op hebben. Levinas noemt als voorbeeld van het andere de ervaring van het il-y-a, de ervaring van het brute zijn, het zijn 'zonder wereld' dat we met onze concepten nauwelijks kunnen benoemen, maar wel kunnen ervaren. Hij verduidelijkt dat aan de 'slapeloosheid', het zinloos wakker liggen in het duister van de nacht. Er is geen oriëntatie, want we zien nergens in het duister enige houvast. Zo overvalt je een besef van betekenisloosheid. Of denk aan depressiviteit: iets drukt je neer zonder dat je er inhoud aan kan geven. Levinas spreekt over het andere/de ander ook in ethische zin. De andere mens die niet tot ons zelf is te herleiden en van buiten op ons toekomt en ons verantwoordelijk maakt. In deze laatste 
opvatting kan het andere/de ander wel tot religieuze transcendentie worden zoals Levinas laat zien. Een ander voorbeeld van invulling van het andere is de ervaring van zin. Als antwoord op de vraag wat het specifieke van de zinervaring is, heb ik zin omschreven als transcendentie in onderscheid van de metafysische en de constructivistische opvatting van zin (Stoker 1996). En Derrida's wending naar het andere?

Alles is ingeschreven in een context, terwijl er anderzijds altijd een 'alteriteit' is die zichzelf van elke context terugtrekt en transcendent is. Op zich hoeft dat niet op religieuze transcendentie te duiden. Derrida wijst ook op de il-y-a ervaringen en op het onbewuste. Ook ontleent hij voor zijn taalfilosofie het een en ander aan Mallarmé. In reactie op het metafysisch denken dat alles wil beheersen, zocht Mallarmé naar het andere in de taal, hij zoekt naar niet-synthetische taalwerelden en daarvoor ontwikkelde hij een experimentele stijl die het andere evoceert (Derrida 1981:187-317). Bij Mallarmé heeft het andere geen religieuze trekken. Derrida legt hem niet als een dichter van het absolute uit (Van der Syde 1997:238). Bij Derrida zelf ligt dat anders. Openstaan voor het andere betekent een nieuw perspectief krijgen. Evink geeft aan hoe de inventie van het andere ook naar religieuze transcendentie bij Derrida kan verwijzen. Hij wijst op de negatieve en positieve kant van de deconstructie:

Enerzijds wordt elk transcendentaal betekende neergehaald in een labyrint van verwijzingen; anderzijds hebben deze verwijzingen een open einde ofwel een oneindige onbeheersbaarheid, en de deconstructie laat deze openheid zien ...In zijn vroegere werk wordt vooral getoond hoe elke vermeende transcendentie is ingeschreven in ... structuren; in het latere ligt de nadruk meer op de openheid voor het andere dat zich aan elke structuur en zingeving onttrekt en soms zelfs in termen van transcendentie ter sprake wordt gebracht. Deze accentverschuiving gaat gepaard met een toenemende belangstelling voor ethische en religieuze vraagstukken

(Evink 2002:77).

Zo is het woord 'God' evenals andere woorden een teken dat zijn inhoud verkrijgt dankzij differenties met andere tekens. 'God' is, anders dan bij Steiner, geen autonome drager van een autonome 
betekenisinhoud. In dat geval zou God een hoogste zijnde zijn, dat als Logos alles fundeert. Antwoord op de betekenis van het woord 'God' geven we door te verwijzen naar andere contexten waarin we het woord 'God' tegenkomen. Dat is de ene kant van Derrida's werkwijze. De andere kant is dat het andere niet door de taal gegrepen kan worden en eraan ontsnapt. Uit de boven gegeven voorbeelden blijkt dat dit in het algemeen geldt. Het geldt a forteriori voor religieuze transcendentie. De negatieve theologie had hier aandacht voor. Daarom was Derrida in haar geïnteresseerd. In zijn Sauf le Nom (1993) is de plaats van God een plaats voorbij de taal, transcendent aan iedere context. In Spectres de Marx (1993) spreekt hij over 'het denken van het andere' als een ervaring van een bevrijdende belofte en van een structureel messianisme en in D'un ton apocalyptique adopté naguère en philosophie (1983) spreekt hij over de openheid voor de toekomst. Hij pleit daar voor een gerichtzijn op de toekomst zonder zekerheid van wat er gaat gebeuren, een apocalyps die zich beperkt tot een onbepaald 'Kom!', een apocalyps die zich openstelt voor het andere dat zich altijd in meerder gedaanten aandient (D'un ton apocalyptique 1983:87-98).

Kortom: transcendentie is in onze cultuur wel degelijk aanwezig. Afwijzing van een Logos-aesthetica houdt niet in dat daarmee betekenis of communicatie onmogelijk is geworden. Integendeel, deconstructie is geen nihilisme, maar biedt het perspectief van een postmetafysische transcendentie die balancerend op de rand van de taal het andere probeert te evoceren.

\section{KUNST EN CHRISTELIJK GELOOF}

Steiner legt een nauw verband tussen kunst en transcendentie. Zowel in het maken van kunst als in haar receptie is er sprake van Gods tegenwoordigheid. Het valt op dat Steiner hier niet de term openbaring gebruikt, toch lijkt hij daarop wel te doelen. Maar hoe zijn z'n uitspraken dan precies te duiden? Kuschner acht Steiner hier uitdagend: hij beperkt Gods tegenwoordigheid niet tot de Schrift of de sacramenten. Juist in de kunst is Gods reële presentie tastbaar (Kuschel 1993:153). Zonder Steiners Logos-esthetica bij te vallen, acht ik zijn verbinding van kunst en transcendentie van groot belang. Kunst kan een medium van openbaring zijn. Tillichs opvatting van religieuze kunst als openbaring verheldert goed Steiners uitspraak over Gods tegenwoordigheid. 
Tillich maakt onderscheid tussen een oorspronkelijke openbaring en een afhankelijke openbaring. In zo'n oorspronkelijke openbaring gaat het om een constellatie die voordien niet bestond. Neem de bijbelse openbaring. Petrus' belijdenis in de omgeving van Caesaréa Philippi is een voorbeeld van een oorspronkelijke openbaring. Zij heeft een objectieve kant (de manifestatie van de openbaring, het daadwerkelijk verschijnen van Jezus als de Christus) en een subjectieve kant, het ontvangen van dit inzicht door Petrus. De openbaring aan de latere gelovigen is afhankelijk van deze oorspronkelijke openbaring aan Petrus en de apostelen. Wij ontvangen namelijk afhankelijk van de bijbeltekst over Petrus' belijdenis, de openbaring die ons doet zeggen dat Jezus de Christus is. Ook hier is een objectieve kant, het 'bijbelse portret' van Jezus als de Christus, en een subjectieve kant, de wijze waarop gelovigen dit als openbaring ontvangen (Tillich 1968:I,140-142).

Structureel is er volgens Tillich geen verschil tussen bijbelse openbaring en openbaring via kunst (Palmer 1984:127-143). Ook in de kunst is er sprake van een oorspronkelijke en een afhankelijke openbaring. De oorspronkelijke openbaring is het gebeuren dat de kunstenaar zelf ten deel viel bij het scheppen van zijn kunstwerk en de afhankelijke openbaring duidt het gebeuren aan dat een beschouwer van het kunstwerk kan overkomen.

Op deze wijze lees ik Steiners uitspraak over Gods tegenwoordigheid in de kunst en over de ontmoeting met een kunstwerk als was het een ontmoeting met God. Daarmee is echter nog niet gezegd in hoeverre kunst in relatie staat met het christelijk (of joodse) geloof. Op zich zou het Steiner om een kunstreligie kunnen gaan, kunst als vervanging van religie zoals Walter Pater en Gustave Flaubert hebben bepleit (Pater 1965:184v; Flaubert 1965:195-197). Bij Steiner lijkt mij dat niet het geval te zijn. Hij verdedigt alleen een Logos-aesthetica volgens welke kunst niet goed mogelijk is zonder transcendentie of God.

Hoe kunnen we Steiners relatie van kunst en transcendentie interpreteren vanuit het christelijk geloof? De christelijke theoloog kan niet volstaan met de constatering van Gods tegenwoordigheid in de kunst, kunst als medium van openbaring. Wat kunst openbaart heeft zijn criterium in de bijbelse openbaring. Zoals Kuschel schrijft:

Und nur unter der Voraussetzung einer schon erfolgten Offenbarung Gottes in Schöpfung und Geschichte kann 
sinnvollerweise auch vom Offenbarsein Gottes in den Schöpfungswerken des Menschen, etwa in Werken der Kunst, die Rede sein. Erst wenn diese Vorausetzung im Akt des vertrauenden Glaubens gemacht ist, kann sinnvollerweise davon geredet werden, das die "Schönheit" eines Kunstwerks die Schönheit Gottes widerspiegelt ...

(Kuschel 1993:163).

Met het geloofsoog kan de tegenwoordigheid van God in het kunstwerk worden gezien en wel in het geloof in Gods openbaar zijn in schepping en geschiedenis. Daarmee is niet bedoeld dat kunst enkel illustratie is bij hetgeen we reeds weten uit de theologie. Het spannende van de relatie tussen kunst en christelijk geloof is dat kunst ons juist op inzichten kan wijzen waarmee de theologie haar voordeel zou kunnen doen (Stoker 2007). Een voorbeeld daarvan is de 'inventio van het andere' dat Derrida in de experimentele literatuur aanwijst. Wil de theoloog Gods transcendentie recht doen, dan dient hij ook de geschikte taalvorm daarvoor te overwegen. Bij Steiner krijgt God een metafysische functie: God als fundament voor betekenis en communicatie. In de deconstructie van de ontotheologie wordt deze metafysische functie van God gedestabliseerd om zo toegang te krijgen tot het andere. Op dat spoor zou de theoloog verder kunnen gaan om Gods transcendentie postmetafysisch te evoceren.

\section{Literatuurverwijzingen}

Altizer, Th. J J 1980. Total Presence: The Language of Jesus and The Language of Today. New York: The Seabury Press.

De Boer, Th. 1999. Het spoor bijster, in De Boer Th. e.a. (reds.), De razende Socrates: hartstocht en rede in de filosofie van Socrates tot Derrida. Baarn/Kapellen: Agora Pelckmans.

Dalferth, I U 2006. Becoming Present: An Inquiry into the Christian Sense of the Presence of God. Leuven: Peeters.

Derrida, J 1981. The Double Session, in Derrida J. Dissemination, 187-316. London: Continuum.

-, 1984. Deconstruction and the other: interview met R Kearny, in Kearny, R (ed.), Dialogues with contemporary continental thinkers. New York.

-, 1987. Psyché: Invention de l'autre, Paris: Galilée.

Evink, E 2002. Transcendentie en inscriptie: Jacques Derrida en de hubris van de metafysica. Delft: Eburon. 
Flaubert, G 1965. An Aesthetic Mysticism, in Ellmann R. \& Feidelson C. The Modern Tradition: Backgrounds of Modern Literature, 193-198. New York: Oxford University Press.

Kuschel, K-J, 1993. Gegenwart Gottes? Zur Möglichkeit theologischer Ästhetik in Auseinandersetzung mit George Steiner, in Lesch, W (Hg.). Theologie und Ästhetische Erfahrung: Beiträge zur Begegnung von Religion und Kunst, Darmstadt:Wissenschaftliche Buchgesellschaft, 145165.

Palmer, M F 1984. Paul Tillich's Philosophy of Art, Berlin: Walter de Gruyter.

Pater, W 1965. The intensity of the Moment, in Ellmann, R \& Feidelson, C (eds), The Modern Tradition: Backgrounds of Modern Literature, New York: Oxford University Press, 182-185.

Prosman, A A A 2007. Geloven na Nietzsche: Nietzsches nihilisme in de spiegel van de theologie. Zoetermeer: Boekencentrum.

Rilke, R M 2000. Archaïsche Apollotorso, in Verstegen, P (vertaling) Nieuwe Gedichten: Het andere deel, 9. Amsterdam: Van Oorschot.

Steiner, G 1991a. Real Presences, Chicago: The Chicago University Press.

-, 1991b. Reële Presenties, in Steiner, G, Heeft waarheid een toekomst? Essays. Baarn: Ambo, 144-164.

-, 1991c. Heidegger opnieuw, in Steiner, G, Heeft waarheid een toekomst? Essays. Baarn: Ambo, 165-189.

-, 1994. A Responsion, in Scott, N A \& Sharp, R A, Reading Steiner, Baltimore \& London: The John Hopkins University, 275-285.

Stoker, W 1996. Is the Quest for Meaning the Quest for God? The Religious Ascription of Meaning in Relation to the Secular Ascription of Meaning. Amsterdam/Atlanta: Rodopi.

-, 2007. God Master in the Arts. www.Ars Disputandi.org vol1

Taylor, M C 1992. Disfiguring: Art, Architecture, Religion. Chicago: The University of Chicago Press.

Tillich, P 1968. Systematic Theology, London: James Nisbet \& Co.

Van der Syde, N 1997. De visie op literatuur van Jacques Derrida. Groningen: Rijksuniversiteit. 